\title{
Mucuna pruriens fiber: nutritional, functional and biological properties
}

\author{
Stephanie VÁZQUEZ ENCALADA ${ }^{1}$, Maira Rubi SEGURA CAMPOS ${ }^{1 *}$ (D)
}

\begin{abstract}
An evaluation was done of the nutritional, functional and antioxidant properties of fiber residues from Mucuna pruriens bean. Nutritional value was quantified in terms of proximate composition, total dietary fiber (TDF), insoluble dietary fiber (IDF), soluble dietary fiber (SDF) and the Van Soest fiber components. Functional value was assayed by measuring water holding capacity (WHC), oil holding capacity (OHC), water absorption capacity (WAbC), water adsorption capacity (WAdC) and organic molecule absorption capacity (OMAC). Emulsifying capacity was also studied. Biological potential was identified by measuring antioxidant properties, as well as phenols and flavonoids content. Nutritionally, M. pruriens fiber registered 26\% of raw fiber, 77.65\% TDF, 69.40\% IDF and 8.25\% SDF. Van Soest fiber components were 61.35\% acid detergent fiber (ADF), $66.86 \%$ neutral detergent fiber (NDF) and $13.62 \%$ acid detergent lignin (ADL). Cellulose and hemicellulose content were 47.73 and $5.51 \%$, respectively. Fiber functional potential values were $3.24 \mathrm{~g} / \mathrm{g}$ sample for WHC, 1.65 for OHC, 3.61 for WAbC, 0.24 for WAdC and 1.19 for OMAC. The highest emulsifying capacity was registered at $\mathrm{pH} 4$. Antioxidant activity was observed in assays as reducing power, DPPH and $\mathrm{ABTS}^{+}$, being possibly attributed to components as phenols $(2624.80 \mu \mathrm{g}$ of gallic acid equivalents $/ \mathrm{mg}$ ), and flavonoids ( $232.71 \mu \mathrm{g}$ catechin equivalents $/ \mathrm{mg})$, quantified at $20 \mathrm{mg} / \mathrm{mL}$.
\end{abstract}

Keywords: antioxidant; fiber; Mucuna pruriens; nutrimental; technological.

Practical application: This manuscript show the properties of $M$. pruriens fiber and suggest it as new fiber source for foods industry.

\section{Introduction}

Food satisfies a primary biological need in humans, and influences behaviors related to consumption and nutritional status. An adequate diet provides a wide variety of different nutrients that fulfill defined biological functions in the organism; the most important nutrients are proteins, lipids, carbohydrates, vitamins, minerals, and fiber (Mora et al., 2013).

Laboratory and medical research have increased awareness of fiber's importance in the human diet. Clinical studies reveal differences in disease patterns between populations and have provided evidence of associations between low fiber diets and increased incidence of numerous chronic diseases. Fibers are classified as insoluble and soluble, each of which exercises different physiological effects in the organism. High soluble fiber intake improves glycemic control, decreases hyperinsulinemia, and lowers plasma lipid concentrations in patients with type II diabetes. Water-insoluble fibers absorb large amounts of water, favoring stool bulking and speeding the passage of waste through the intestines, which may reduce the risk of colon cancer (Moure et al., 2004).

Dietary fiber can be used as an ingredient in functional foods when specific processing functions or final product benefits are desired. In a balanced diet, the combination of dietary fiber with at least one additional property can provide health benefits (Agudelo et al., 2015). Demand for single fiber ingredient products continues to grow (Sloan 2001). With a well-established market for dietary fiber, new ingredients may be welcome, particularly those that can be associated with the possibility of obtaining nutritional requirements through normal dietary practices.

On-going food scarcity, malnutrition, and poverty combined with population growth in developing countries drive researchers to continually broaden their search for new plant species with potential benefits for humans. Seeds from wild plants are thus receiving more attention because they are well adapted to adverse environmental conditions, resist to disease and pests, and may have promising nutritional qualities (Kalidass \& Mahapatra, 2014). Mucuna pruriens is a member of the Fabaceae family, composed of approximately 650 genera and 2,000 species. This legume produces pods about $12 \mathrm{~cm}$ long that contain about 7 seeds of varied coloration from beige to brown and black, and even striped. Known variously as "velvet bean", "lion bean", "nescafe", and "cowage", among others, it originated in India, and is now cultivated in Sri Lanka, Malaysia, southeastern Asia, and the tropics of Central and South America (Leite et al., 2015). This legume is an important element in the Ayurvedic system of medicine, it is also a rich source of protein, peptides, and fiber. Its constituents make it a promising option for development of new products.

The present study objective was to evaluate the nutritional, functional, and biological properties of fiber residues from M. pruriens with a view to its use as a potential fiber source for food enrichment. 


\section{Materials and methods}

\subsection{M. pruriens fiber residues}

Mucuna pruriens pods were acquired in the state of Yucatan, Mexico, completely dried and threshed to remove the seeds. Ripe, dry seeds were ground in a disk mill (model 4-E Quaker, Mill Straub Co., Philadelphia, PA, USA) and the resulting meal sifted through 4.76- and 2.38-mm screens to remove the smallest particles before air classification. Hulls were removed using a fluidizing air bed and the remaining meal milled in a Cyclotec mill (Tecator, Höganas, Sweden) until passing through a $0.841 \mathrm{~mm}$ screen.

\subsection{Nutritional potential of M. pruriens fiber residues}

\section{Proximate composition of $M$. pruriens fiber residues}

Standard Official Methods of Analysis (1997) procedures were used to quantify nitrogen (method 954.01), fat (method 920.39), ash (method 925.09), crude fiber (method 962.09) and moisture (method 925.09) contents in the M. pruriens fiber residues.

\section{Total, insoluble and soluble dietary fiber (TDF, IDF and SDF)}

Dietary fibers (TDF, IDF and SDF) were quantified according to Prosky et al. (1988). Briefly, $1 \mathrm{~g}$ sample was placed in an Erlenmeyer flask and $50 \mathrm{~mL} 0.05 \mathrm{~N}$ phosphate buffer at $\mathrm{pH} 6$ added. Flasks were placed in a water bath at $100^{\circ} \mathrm{C}, 0.1 \mathrm{~mL}$ thermostable $\alpha$-amylase (Sigma A-3306, USA) added and the solution stirred at $60 \mathrm{rpm}$ for 15 min using a mixer (Stir Pak Heavy Duty Mixer System, Cole-Parmer, USA). After cooling, $\mathrm{pH}$ was adjusted to 7.5 using 1.0 $\mathrm{M} \mathrm{NaOH}$. The flasks were placed in a water bath at $60{ }^{\circ} \mathrm{C}$, $0.1 \mathrm{~mL}$ protease (Sigma P-3910, USA) added, and the solution stirred at $60 \mathrm{rpm}$ for $30 \mathrm{~min}$ (Stir Pak Heavy Duty Mixer System, Cole-Parmer, USA). After cooling, $\mathrm{pH}$ was adjusted to 4.0 with $1.0 \mathrm{M} \mathrm{HCl}$. For a third time, the flasks were placed in a water bath at $60^{\circ} \mathrm{C}, 0.3 \mathrm{~mL}$ amyloglucosidase (Sigma A-9913, USA) added, and the solution stirred for $30 \mathrm{~min}$. Ethanol (95 g/kg ethanol), preheated at $60{ }^{\circ} \mathrm{C}$, was added to the flasks at a $1: 4(\mathrm{v} / \mathrm{v})$ ratio, and the contents vacuum filtered into crucibles containing celite (Sigma C-8656, USA). The remaining residue was washed three times with $20 \mathrm{~mL} 780 \mathrm{~g} / \mathrm{kg}$ ethanol, twice with $10 \mathrm{~mL} 950 \mathrm{~g} / \mathrm{kg}$ ethanol, and twice with $10 \mathrm{~mL}$ acetone. Crucible contents were dried at $105^{\circ} \mathrm{C}$. Protein content $(\mathrm{N} x$ 6.25) was quantified for the residue in two of the crucibles, and the contents of the remaining crucibles were incinerated at $550{ }^{\circ} \mathrm{C}$ for $4 \mathrm{~h}$. Total dietary fiber (TDF) content was calculated as follows:

$\operatorname{TDF}(\%)=[$ residue mass $(g)-\operatorname{protein}(g)-$ ash $(g)-$ blank $] /$ sample mass $(g) \times 100$

Insoluble dietary fiber (IDF) was determined according to the methodology described by Prosky et al. (1988). It is similar to TDF quantification except for addition of $95 \%$ ethanol at a $1: 4$ ratio.

Soluble dietary fiber (SDF) was calculated according to Prosky et al. (1988), as the difference between TDF and IDF: $\mathrm{SDF}=\mathrm{TDF}-\mathrm{IDF}$.

\section{Van Soest fiber components}

Acid detergent fiber (ADF) content was measured by first oven drying sample to dry matter at $55^{\circ} \mathrm{C}$ in dry $50 \mathrm{~mL}$ fritted glass crucibles overnight at $100{ }^{\circ} \mathrm{C}$, and hot weight (W1) recorded to the nearest $0.1 \mathrm{mg}$. Sample was weighed (W2) (approximately 0.9 to $1.1 \mathrm{~g}$, weight accurate to $0.1 \mathrm{mg}$ ) into a Berzelius beaker. One hundred milliliters $(100 \mathrm{~mL})$ of an acid-detergent solution $(20 \mathrm{~g}$ cetyltrimethylammonium bromide technical grade in $1 \mathrm{~L} 1.0 \mathrm{~N}$ sulfuric acid) at room temperature was added to the beaker. This solution was heated to boiling within 5-10 min, and heat reduced as boiling began to avoid foaming. The solution was refluxed for $60 \mathrm{~min}$ from boil onset, adjusting boil to a slow, even level. After $30 \mathrm{~min}$, the sides of the beaker were rinsed with a minimal amount of acid detergent solution. The sample was filtered through a tared fritted glass crucible, using minimal vacuum. The Berzelius beaker was washed with boiling water to insure complete transfer of all fiber particles into the crucible. The residue was rinsed twice with $30-40 \mathrm{~mL}$ acetone by filling the crucible with the vacuum off and allowing a minimum of 15 to $30 \mathrm{sec}$ ( $2 \mathrm{~min}$ recommended) before vacuuming dry. Residue was dried overnight in a forced-air oven at $100{ }^{\circ} \mathrm{C}$ and weighed hot, recording weight (W3) to the nearest $0.1 \mathrm{mg}$. The percentage of acid detergent fiber (ADF) was calculated as follows (Van et al., 1991):

$\% A D F(D M$ basis $)=(W 3-W 1 / W 2) \times 100$

Where: W1 is tare weight of crucible in grams; W2 is initial sample weight in grams; and W3 is dry weight of crucible and dry fiber in grams.

Neutral detergent fiber (NDF) content was quantified with a protocol similar to that for ADF. Neutral-detergent solution $(100 \mathrm{~mL})$ was added to the sample and the solution prepared with distilled water, sodium borate, EDTA, lauryl sulfate, 2-ethoxyethanol and disodium phosphate. The $\mathrm{pH}$ was adjusted to 6.9-7.1 (Van et al., 1991).

Acid detergent lignin (ADL) content was quantified with a protocol similar to that for ADF. A $72 \% \mathrm{H}_{2} \mathrm{SO}_{4}$ solution $(100 \mathrm{~mL})$ was added to the sample. The crucible with sample was burned in a muffle furnace at $500{ }^{\circ} \mathrm{C}$ for 2 hours. The crucible was weighed to the nearest $0.1 \mathrm{mg}$ (W3) (Official Methods of Analysis, 1997).

\section{Cellulose and hemicellulose content}

$\%$ Cellulose $=\operatorname{ADF}($ Cellulose, lignin, cutin $)-\operatorname{ADL}($ Lignin, cutin $)$

$\%$ Hemicellulose $=\operatorname{NDF}($ Hemicellulose, cellulose, lignin, cutin $)-\operatorname{ADF}($ Cellulose, lignin, cutin $)$

\subsection{Functional potential of M. pruriens fiber residues}

\section{Water-Holding (WHC) and Oil-Holding Capacity (OHC)}

Both WHC and OHC were quantified following Chau et al. (1997). Fiber residue $(1 \mathrm{~g})$ was stirred into $20 \mathrm{~mL}$ distilled water or $10 \mathrm{~mL}$ corn oil for one minute. These suspensions were then centrifuged for $30 \mathrm{~min}$ at $2250 \times \mathrm{g}$ and supernatant volume measured. The results were expressed as $\mathrm{WHC}=\mathrm{g}$ water held per $g$ fiber residue, and $\mathrm{OHC}=\mathrm{g}$ oil held per $\mathrm{g}$ fiber residue. 


\section{Water Adsorption Capacity (WAdC)}

Sample (1 $\mathrm{g}$ d.b.) was placed in an equilibrium micro-environment at $98 \%$ relative humidity and left there until reaching constant weight $(48 \mathrm{~h})$. The result was expressed as $\mathrm{WAdC}=\mathrm{g}$ water per $\mathrm{g}$ sample (Chen et al., 1984).

\section{Water absorption capacity (WAbC)}

Following the relevant American Association of Cereal Chemists (1984) method (88-04), water was added until saturation to $2 \mathrm{~g}$ (d.b.) sample, and the solution centrifuged at $2000 \times \mathrm{g}$ for $10 \mathrm{~min}$ in a Beckman GS-15R centrifuge. Excess water was discarded, and the residue weighed. Approximate WAbC was calculated by dividing the increase in sample weight $(\mathrm{g})$ by the quantity of water needed to complete original sample weight $(2 \mathrm{~g}$ d.b.) to $15 \mathrm{~g}$. Exact quantification of $\mathrm{WAbC}$ was done by placing samples in four tubes, adding different quantities of water to bracket the measurement (1.5 and $0.5 \mathrm{~mL}$ water above original weight, and 1.5 and $0.5 \mathrm{~mL}$ water below; one amount per tube), agitating vigorously in a vortex for $2 \mathrm{~min}$, and centrifuging at $2000 x \mathrm{~g}$ for 10 min in a Beckman GS-15R centrifuge. The supernatant was discarded, and the residue weighed. The results were expressed as $\mathrm{WAbC}=\mathrm{g}$ water absorbed per $\mathrm{g}$ sample.

\section{Organic Molecule Absorption Capacity (OMAC)}

This parameter was determined following Zambrano et al. (2001) method. Sample (3 g d.b.) was placed in an excess quantity of corn oil for $24 \mathrm{~h}$ at $25^{\circ} \mathrm{C}$, and then centrifuged for $15 \mathrm{~min}$ at $2000 \times g$ and $25^{\circ} \mathrm{C}$ in a Beckman GS-15R centrifuge. The result was expressed as g oil per $\mathrm{g}$ sample.

\section{Emulsifying Capacity (EC)}

Following Chau et al. (1997), $100 \mathrm{~mL}$ of a $2 \mathrm{~g} / 100 \mathrm{~mL}$ fiber suspension were homogenized in a Caframo RZ-1 homogenizer at $2000 \mathrm{rpm}$ for $2 \mathrm{~min}$. Corn oil (100 mL) (Mazola, CPI International) was added to each sample and they were homogenized for $1 \mathrm{~min}$. The resulting emulsions were centrifuged in $15 \mathrm{~mL}$ graduated centrifuge tubes at $1200 \times \mathrm{g}$ for $5 \mathrm{~min}$, and emulsion volume measured. Results were expressed as $\mathrm{EC}=\mathrm{mL}$ emulsified layer volume of the complete $100 \mathrm{~mL}$ layer in the centrifuge tube.

\subsection{Biological potential of M. pruriens fiber residues: antioxidant activity}

\section{Reducing power assay}

This property was determined according to Oyaizu (1996). A fixed volume $(1 \mathrm{~mL})$ of test samples at different concentrations (1-20 $\mu \mathrm{g} / \mathrm{mL})$ was mixed with $2.5 \mathrm{~mL}$ phosphate buffer and $1 \%$ potassium ferricyanide $\left[\mathrm{K}_{3} \mathrm{Fe}(\mathrm{CN})_{6}\right]$. These mixtures were incubated at $50{ }^{\circ} \mathrm{C}$ for $20 \mathrm{~min}, 2.5 \mathrm{~mL}$ trichloroacetic acid added, and centrifuged at $3000 \mathrm{rpm}$ for $10 \mathrm{~min}$. The upper layer of the solution was separated and mixed with $2.5 \mathrm{~mL}$ distilled water and $0.5 \mathrm{~mL} \mathrm{FeCl}_{3}$. Absorbance was measured against a blank at $700 \mathrm{~nm}$. Increased absorbance of the reaction mixture indicated increased reducing power. Gallic acid was used as a positive control.

\section{$\mathrm{Cu}^{2+}$ chelating activity}

This parameter was measured according to Saiga et al. (2003). Briefly, $250 \mu \mathrm{L}$ sodium acetate buffer ( $50 \mathrm{mM}, \mathrm{pH} 6.0$ ), $250 \mu \mathrm{L} \mathrm{Cu}$ (II) standard solution $(20 \mathrm{mM})$, and $25 \mu \mathrm{L} 0.1 \%$ pyrocatechol violet solution were mixed in a test tube. The mixture was allowed to react for $5 \mathrm{~min}$ at room temperature and $250 \mu \mathrm{L}$ sample $(20-100 \mu \mathrm{g} / \mathrm{mL})$ added. Absorbance was measured at $632 \mathrm{~nm}$, and results expressed as chelating activity $(\%)=[($ sample absorbance-control absorbance)/sample absorbance] x 100 .

$\alpha, \alpha$-diphenyl- $\beta$-picrylhydrazyl (DPPH)

Samples (1-20 $\mu \mathrm{g} / \mathrm{mL})$ were reacted with the stable DPPH radical in an ethanol solution. The reaction mixture consisted of $100 \mu \mathrm{L}$ sample, $1 \mathrm{~mL}$ ethanol and $3.9 \mathrm{~mL} 1 \times 10^{-4} \mathrm{M} \mathrm{DPPH}$ radical solution in ethanol. When DPPH reacts with an antioxidant compound that can donate a hydrogen it is reduced. A UV-VIS spectrophotometer was used to measure changes in color (from deep violet to light yellow) at $515 \mathrm{~nm}$ after 1, 30 and $60 \mathrm{~min}$ of reaction. The DPPH residual was calculated as follows:

DPPH residual $=[1-($ Abs Control - Abs Sample $) /$ Abs Control $] \times 100$

\section{2,2'-Azinobis-(3-Ethylbenzothiazoline-6-Sulfonic Acid, ABTS $^{\cdot+}$ ) decolorization assay}

This property was determined according to Rhee et al. (2004). The ABTS $^{*+}$ radical cation was produced by reacting 2,2'-azino-bis(3-ethylbenzthiazoline-6-sulphonic) acid (ABTS) with potassium persulfate. Stock solution was prepared by dissolving $2 \mathrm{mM}$ ABTS in $50 \mathrm{~mL}$ phosphate-buffered saline. The ABTS radical ${ }^{++}$cation was produced by reacting $10 \mathrm{~mL}$ ABTS stock solution with $40 \mu \mathrm{L} 70 \mathrm{mM} \mathrm{K}_{2} \mathrm{~S}_{4} \mathrm{O}_{8}$ solution and allowing the mixture to stand in darkness at room temperature for 16-17 h before use. Antioxidant compound content was analyzed by diluting the $\mathrm{ABTS}^{\cdot+}$ solution with PBS to an absorbance of $0.800 \pm 0.030 \mathrm{AU}$ at $734 \mathrm{~nm}$. After adding $990 \mu \mathrm{L}$ diluted ABTS ${ }^{\bullet+}$ solution (at $734 \mathrm{~nm}=0.800 \pm 0.030$ ) to $10 \mu \mathrm{L} 6$-hydroxy-2,5,7,8 -tetramethylchroman-2-carboxylic acid (Trolox) standard (final concentration 0.5-3.5 mM) in PBS, absorbance was read at room temperature exactly $6 \mathrm{~min}$ after initial mixing. To calculate the Trolox equivalent antioxidant coefficient (TEAC), the slope of the absorbance inhibition percentage vs. antioxidant concentration plot was divided by the slope of the Trolox plot.

\section{Total phenolic content}

Phenolic compounds content was measured according to Georgé et al. (2005). A volume $(250 \mu \mathrm{L})$ containing different sample concentrations $(1-20 \mu \mathrm{g} / \mathrm{mL})$ was mixed with $1250 \mu \mathrm{l}$ Folin-Ciocalteu reagent for 30 seconds in a vortex. The mixture was allowed to react for $2 \mathrm{~min}$ at room temperature, $400 \mu \mathrm{L}$ $\mathrm{Na}_{2} \mathrm{CO}_{3}(75 \mathrm{mg} / \mathrm{L})$ added, and the mixture allowed to react for $15 \mathrm{~min}$ at $50{ }^{\circ} \mathrm{C}$. Absorbance was measured at $760 \mathrm{~nm}$. Calculation of total phenolic content was done by comparing a standard curve $(0-640 \mu \mathrm{g} / \mathrm{mL}$ gallic acid) to each sample's absorbance. The results were expressed as micrograms gallic acid equivalents per mg sample. 


\section{Total flavonoid content}

Flavonoid content was quantified following Lee et al. (2003). Sample $(250 \mu \mathrm{L})$ and $250 \mu \mathrm{L} 0.5 \% \mathrm{NaNO}_{2}(\mathrm{w} / \mathrm{v})$ were mixed. After $5 \mathrm{~min}, 125 \mu \mathrm{L} 10 \% \mathrm{AlCl}_{3}$ and $124 \mu \mathrm{L} 1.0 \mathrm{M} \mathrm{NaOH}$ were added and absorbance measured at $490 \mathrm{~nm}$. Content was calculated by comparing a standard curve $(0-640 \mu \mathrm{g} / \mathrm{mL}$ catechin) to each sample's absorbance. The results were expressed as micrograms catechin equivalents per mg sample.

\subsection{Statistical analysis}

The results were analyzed with descriptive statistics including a central tendency and dispersion measures. All analyses were done following Montgomery (2003) and run with the Statgraphics Plus version 5.1 software.

\section{Results and discussion}

\subsection{Nutritional potential of M. pruriens fiber residues}

Nutrient evaluation of the fiber residues suggested that $M$. pruriens is a potential source of fiber powders. Proximal analysis showed the residues to contain $7.36 \%$ moisture, $26.00 \%$ fiber, $11.29 \%$ protein, $8.44 \%$ fat, $3.19 \%$ ash and $51.06 \%$ NFE. Dietary fiber contents were $77.65 \%$ TDF, 69.40\% IDF, and 8.25\% SDF. Van Soest fiber components values were $61.35 \%$ for ADF, $66.86 \%$ for NDF and $13.62 \%$ for ADL. Finally, cellulose content was $47.73 \%$ and hemicellulose content was $5.51 \%$. Commercial fiber products commonly have greater than $50 \%$ TDF content, less than 9\% moisture content, a low lipid content, a low caloric value, and neutral flavor and taste (Larrauri, 1999). The evaluated M. pruriens fiber residues largely meet these conditions, making them a promising ingredient in high dietary fiber formulated foods.

High dietary fiber diets are intended for the prevention, reduction and treatment of diseases such as coronary heart disease. The physiological effects of these diets are linked to dietary fiber's physicochemical and functional properties. The SDF:IDF ratio is important for both dietary and functional properties. Fiber sources suitable for use as a food ingredient should have an SDF/IDF ratio near 1:2; the $M$. pruriens fiber residues had a ratio higher than this suggested level. TDF contents are usually ranked as low (30 to 50\%); intermediate (50 to 70\%); and high (70 to 90\%) (Jiménez-Colmen ero et al., 2001; Figuerola et al., 2005; Rodríguez et al., 2006). On this scale the evaluated $M$. pruriens fiber residues qualify as high content. The residues' proximal composition, SDF/IDF ratio, and Van Soest components suggest that $M$. pruriens fiber is a good alternative fiber for food system applications.

\subsection{Functional properties of M. pruriens fiber residues}

Quantification of the functional properties of $M$. pruriens fiber residues showed them to have values that could make them a useful ingredient in foods. The values were $3.24 \mathrm{~g}$ water held / $\mathrm{g}$ fiber residue for WHC, $1.65 \mathrm{~g}$ oil held per $\mathrm{g}$ fiber residue for $\mathrm{OHC}, 0.24 \mathrm{~g}$ water per $\mathrm{g}$ sample for WAdC, $3.61 \mathrm{~g}$ water absorbed per g sample for WAbC and $1.19 \mathrm{~g}$ oil per g sample for OMAC (Figure 1). Emulsifying capacity was $57.94 \%$ at $\mathrm{pH} 2,63.89 \%$ at $\mathrm{pH} 4,62.43 \%$ at $\mathrm{pH} 6,59.22 \%$ at $\mathrm{pH} 8$, and $58.93 \%$ at $\mathrm{pH} 10$
(Figure 2). A fiber's hydration properties are important because liquid retention influences ingredient functionalities, product yield, and storage stability (Agudelo et al., 2015).

From a technological and physiological standpoint, parameters such as WAbC are vital properties. This parameter in particular is related to the porous structure of the polysaccharide chain matrix which attracts and retains water through its hydrogen bonds. The fiber WAbC values in this study were lower than reported for fiber from other species such as asparagus (9.92-14.32 g/ water/ sample) (Agudelo et al., 2015), peach (12.6 mL water/g) (Grigelmo-Miguel \& Martín-Belloso, 1999), lemon (11 mL water/g) (Lario et al., 2004), and cocoa shell (5 mL water/g) (Lecumberri et al., 2007). Its WAbC values indicate that $M$. pruriens fiber is not apt for use as a texture and viscosity modifier but could be used as a calorie reducer.

Another important functional property in food technology is the OMAC. This property is the maximum amount of oil (in grams) that can be retained by $1 \mathrm{~g}$ of dry matter immersed in excess oil while under a force (centrifugation); in other words, it represents the capacity of $M$. pruriens fiber to absorb oil. Fat absorption capacity depends on surface properties, overall charge density, thickness, and the hydrophobic nature of the fiber particle (Femenia et al., 1997). The OMAC value for M. pruriens fiber was similar to those reported for apple pomace and orange peel (0.6-1.8 mL/g) (Figuerola et al., 2005), unripe plantain (2 mL/g) (Rodríguez et al., 2006), and flours of pea (1.06-1.17 g/g) and pigeon pea (Cajanus cajan L.) (0.96-0.98 g/g) (Kaur et al., 2007). Its OMAC values indicate $M$. pruriens fiber could be a useful additive in food systems which require emulsifying properties to retain flavor, improve palatability and increase use life (Alarcón et al., 2013).

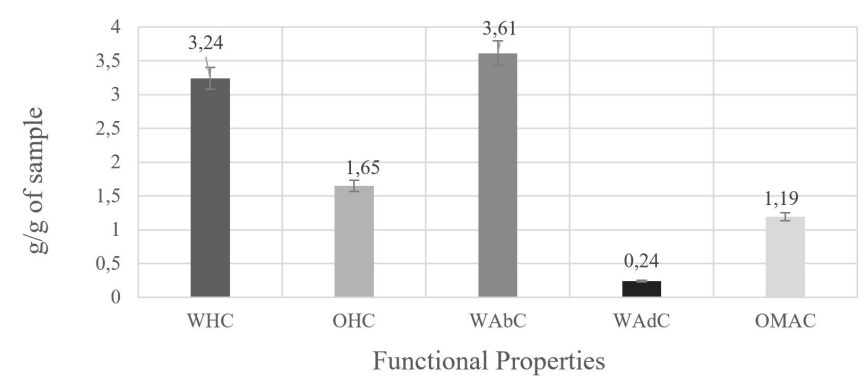

Figure 1. Functional properties of fiber residues from $M$. pruriens. Data are presented as means $(n=3) \pm$ standard deviation.

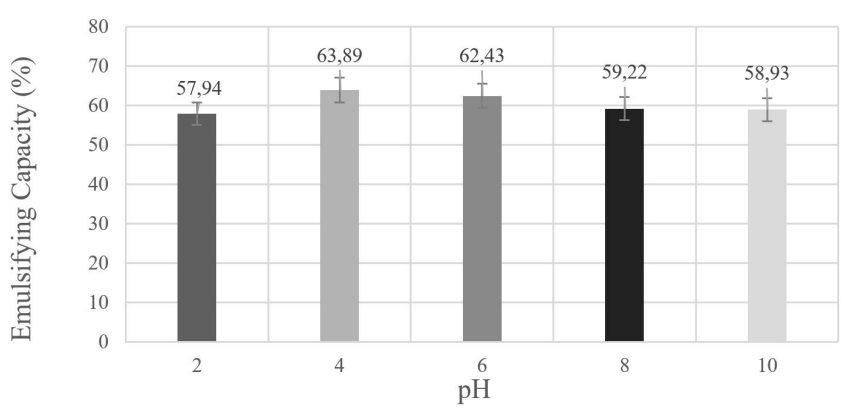

Figure 2. Emulsifying capacity (\%) of fiber residues from $M$. pruriens. Data are presented as means $(n=3) \pm$ standard deviation. 


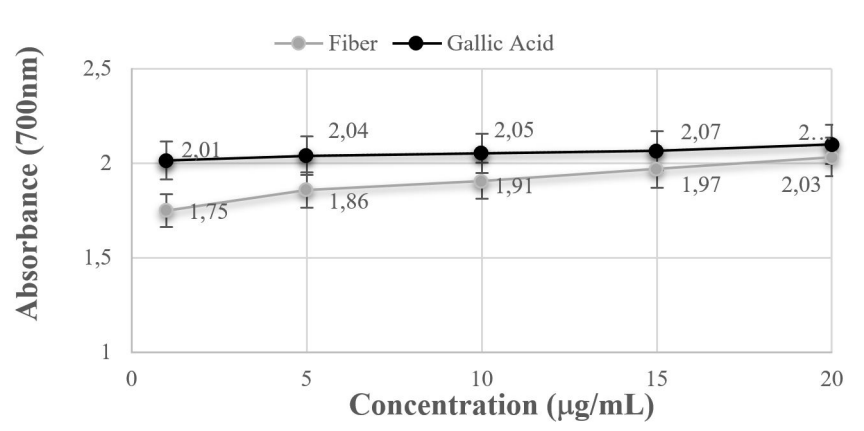

Figure 3. Ferric reducing power of fiber residues from $M$. pruriens and gallic acid as standard. Data are presented as means $(\mathrm{n}=3) \pm$ standard deviation.

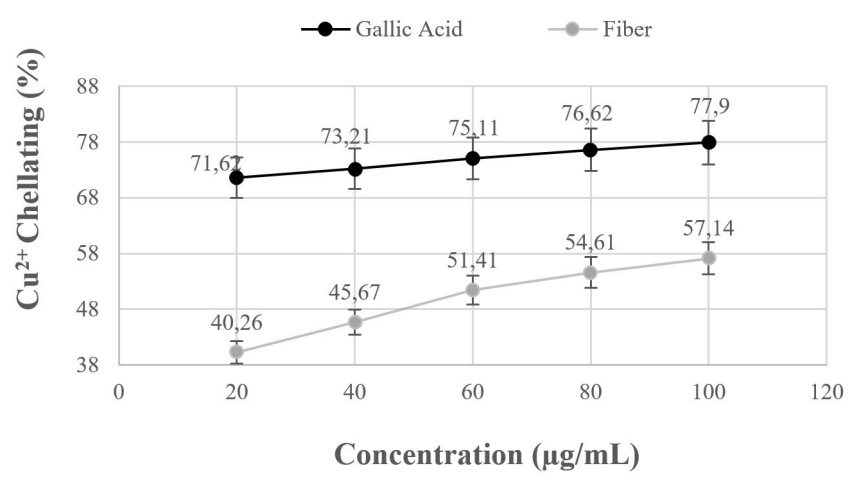

Figure 4. Chelating of metal ions $\mathrm{Cu}^{2+}$ of fiber residues from $M$. pruriens and gallic acid as standard. Data are presented as means $(n=3)$ \pm standard deviation.

(a)

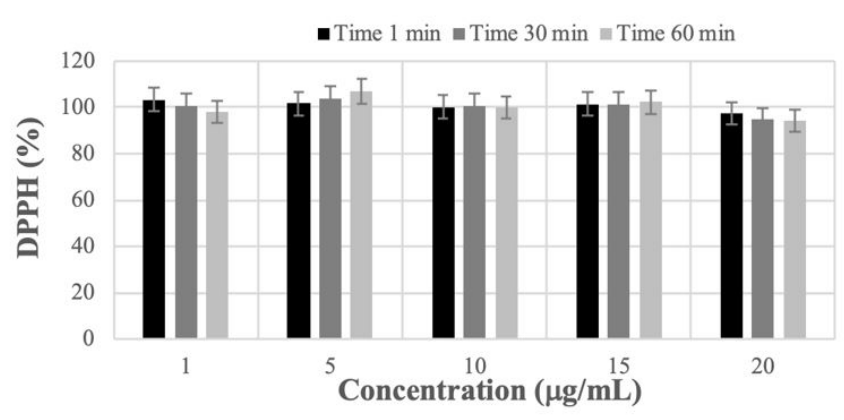

(b)

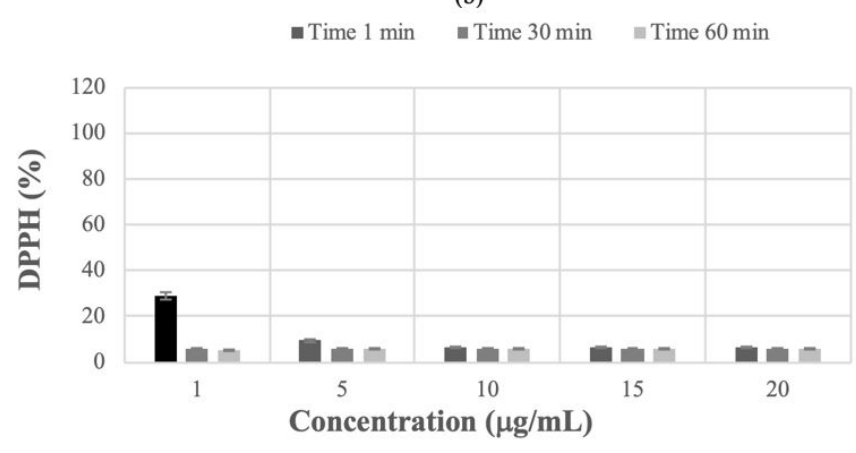

Figure 5. Percentage of DPPH residual: (a) M. pruriens fiber, (b) gallic acid as standard. Data are presented as means $(n=3) \pm$ standard deviation.

\subsection{Biological activity of $M$. pruriens fiber residue}

Reducing power is quantified via the color change, from the yellow color of the test solution to various shades of green and blue, caused by reduction of the $\mathrm{Fe}^{3+}$ ferricyanide complex to the ferrous form by reducers (i.e. antioxidants) (Figure 3). Measurement of formation of Perl's Prussian blue at $700 \mathrm{~nm}$ is a tool for monitoring $\mathrm{Fe}^{2+}$ concentration. The $M$. pruriens fiber residues exhibited lower reducing power than the gallic acid standard, although the difference was not significant at 15 and $20 \mu \mathrm{g} / \mathrm{mL}$. Chelation of $\mathrm{Cu}^{2+}$ metal ions by the fiber was lower than that of gallic acid, with activity ranging from $40.26 \%$ at $20 \mu \mathrm{g} / \mathrm{mL}$ to $57.14 \%$ at $100 \mu \mathrm{g} / \mathrm{mL}$ (Figure 4). Fiber residue antioxidant activity was also lower than that of gallic acid that registered values of DPPH residual below $6 \%$ after $60 \mathrm{~min}$ at all concentrations (Figure 5). The ABTS decolorization assays showed that higher concentrations of the fiber residues are needed to attain TEAC values comparable to those of Trolox. Values for the fiber residues were $0.43(1 \mu \mathrm{g} / \mathrm{mL})$ to 3.09 $(20 \mu \mathrm{g} / \mathrm{mL})$, while those for Trolox were $0.44(0.5 \mu \mathrm{g} / \mathrm{mL})$ to $3.44(3.5 \mu \mathrm{g} / \mathrm{mL}$ ) (Figure 6). Phenolic content of the fiber residues ranged from $132.48 \mu \mathrm{g}(1 \mathrm{mg} / \mathrm{mL})$ to $2624.80 \mu \mathrm{g}$ $(20 \mathrm{mg} / \mathrm{mL}$ ) of gallic acid equivalents $/ \mathrm{mg}$ content (Figure 7). Fiber residue flavonoid content ranged from $6.89 \mu \mathrm{g}(1 \mathrm{mg} / \mathrm{mL})$ to $232.71 \mu \mathrm{g}(20 \mathrm{mg} / \mathrm{mL})$ catechin equivalents $/ \mathrm{mg}$ sample. The above bioactivity values suggest that $M$. pruriens fiber is a potential ingredient in functional foods, and that its inclusion could provide health benefits.

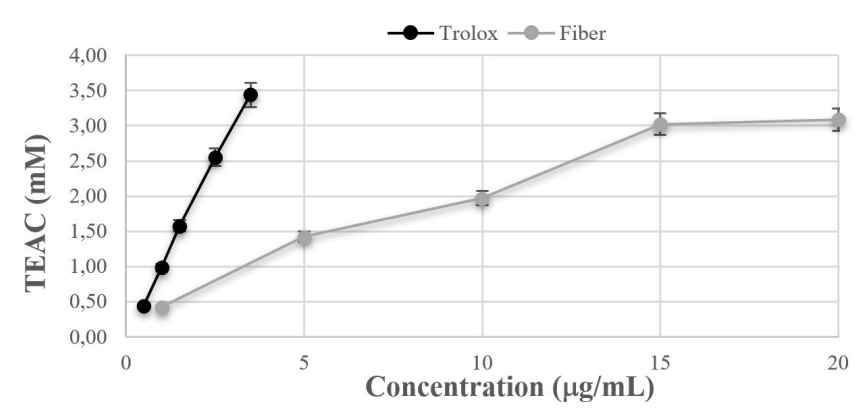

Figure 6. TEAC values of fiber residues from $M$. pruriens and trolox as standard. Data are presented as means $(n=3) \pm$ standard deviation.

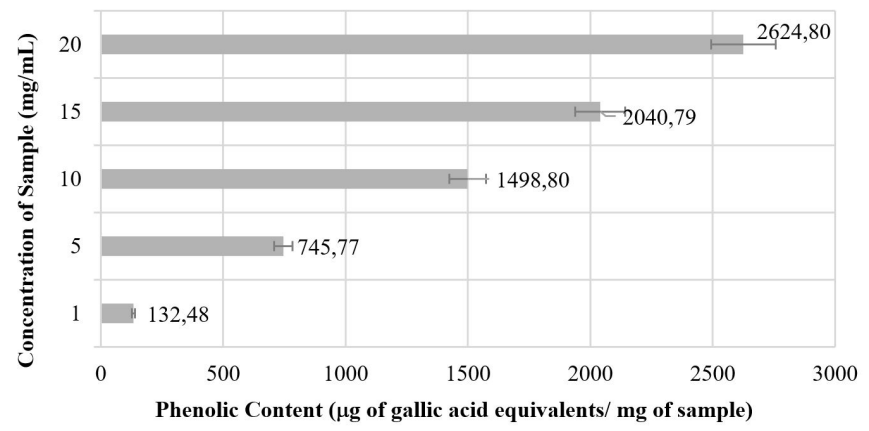

Figure 7. Phenolic content of fiber residues from $M$. pruriens. Data are presented as means $(n=3) \pm$ standard deviation. 


\section{Conclusion}

The nutritional, functional and biological properties of $M$. pruriens fiber suggest it as new dietary fiber source for use in formulation of food products aimed at meeting general nutritional needs and to reduce the risk factors associated with non-transmissible chronic diseases, due its antioxidant potential. Because results suggesting to $M$. pruriens as fiber potential source more studies are necessary for suggest it as ingredient of functional foods and diet therapy alternative of diseases prevention.

\section{References}

Agudelo, E., Restrepo, D., \& Cartagena, J. (2015). Chemical, physicochemical and functional characteristics of dietary fiber obtained from asparagus byproducts (Asparagus officinalis L.). Revista Facultad Nacional de Agronomía, 68(1), 7533-7544. http:// dx.doi.org/10.15446/rfnam.v68n1.47842.

Alarcón, M., López, J., \& Restrepo, D. (2013). Caracterización de la funcionalidad tecnológica de una fuente rica en fibra dietaria obtenida a partir de cáscara de plátano. Revista Facultad Nacional de Agronomía, 66(1), 6959-6968.

American Association of Cereal Chemists - AACC. (1984). Approved Methods of the American Association of Cereal Chemistry. St Paul: AACM.

Chau, C., Cheung, K., \& Wong, Y. (1997). Functional properties of protein concentrates from three Chinese indigenous legume seeds. Journal of Agricultural and Food Chemistry, 45(7), 2500-2503. http:// dx.doi.org/10.1021/jf970047c.

Chen, J., Piva, M., \& Labuza, T. (1984). Evaluation of Water Binding Capacity (WBC) of Food Fiber Sources. Journal of Food Science, 49(1), 59-63. http://dx.doi.org/10.1111/j.1365-2621.1984.tb13668.x.

Femenia, A., Lefebvre, C., Thebaudin, Y., Robertson, J., \& Bourgeois, C. (1997). Physical and sensory properties of model foods supplemented with cauliflower fiber. Journal of Food Science, 62(4), 635-639. http:// dx.doi.org/10.1111/j.1365-2621.1997.tb15426.x.

Figuerola, F., Hurtado, M., Estévez, A., Chiffelle, I., \& Asenjo, F. (2005). Fibre concentrates from apple pomace and citrus peel as potential fibre sources for food enrichment. Food Chemistry, 91(3), 395-401. http://dx.doi.org/10.1016/j.foodchem.2004.04.036.

Georgé, S., Brat, P., Alter, P., \& Amiot, M. (2005). Rapid determination of polyphenols and vitamin C in plant-derived products. Journal of Agricultural and Food Chemistry, 53(5), 1370-1373. http://dx.doi. org/10.1021/jf048396b. PMid:15740008.

Grigelmo-Miguel, N., \& Martín-Belloso, O. (1999). Comparison of dietary fibre from by-products of processing fruits and greens and from cereals. Lebensmittel-Wissenschaft + Technologie, 38(8), 503508. http://dx.doi.org/10.1006/fstl.1999.0587.

Jiménez-Colmenero, F., Carballo, J., \& Cofrades, S. (2001). Healthier meat and meat products: their role as functional foods. Meat Science, 59(1), 5-13. http://dx.doi.org/10.1016/S0309-1740(01)00053-5. PMid:22062500.

Kalidass, C., \& Mahapatra, A. (2014). Evaluation of the proximate and phytochemical composition of an underexploited legume Mucuna pruriens var. utilis (Wall ex Wight) L.H. Bailey. International Food Research Journal, 21(1), 303-308.

Kaur, M., Singh, K., \& Singh, N. (2007). Comparative study of the functional, thermal and pasting properties of flours from different field pea (Pisum sativum L.) and pigeon pea (Cajanus cajan L.) cultivars. Food Chemistry, 104(1), 259-267. http://dx.doi.org/10.1016/j. foodchem.2006.11.037.

Lario, Y., Sendra, E., García, J., Fuentes, C., Sayas-Barberá, E., FernándezLópez, J., \& Pérez-Alvarez, J. (2004). Preparation of high dietary fiber powder from lemon juice by-products. Innovative Food Science \& Emerging Technologies, 5(1), 113-117. http://dx.doi.org/10.1016/j. ifset.2003.08.001.

Larrauri, J. (1999). New approaches in the preparation of high dietary fibre powders from fruits by-products. Trends in Food Science \& Technology, 10(1), 3-8. http://dx.doi.org/10.1016/S09242244(99)00016-3.

Lecumberri, E., Mateos, R., Izquierdo-Pulido, M., Rupérez, P., Goya, L., \& Bravo, L. (2007). Dietary fiber composition, antioxidant capacity and physicochemical properties of a fibre-rich product from cocoa (Theobroma cacao L.). Food Chemistry, 104(3), 948-954. http:// dx.doi.org/10.1016/j.foodchem.2006.12.054.

Lee, K., Kim, Y., Lee, H., \& Lee, C. (2003). Cocoa has more phenolic phytochemicals and a higher antioxidant capacity than teas and red wine. Journal of Agricultural and Food Chemistry, 51(25), 7292-7295. http://dx.doi.org/10.1021/jf0344385. PMid:14640573.

Leite, R., Silva, A., Nascimento, A., Pereira, A., \& Souza, J. (2015). Nutritional composition, phytochemicals and microbiological quality of the legume, Mucuna pruriens. African Journal of Biotechnology, 14(8), 676-682. http://dx.doi.org/10.5897/ AJB2014.14354.

Mora, Y., Contreras, J., Aguilar, C., Meléndez, P., De la Garza, I., \& Rodriguez, R. (2013). Chemical composition and functional properties from diferente sources of dietary fiber. American Journal of Food and Nutrition, 1(3), 27-33.

Moure, A., Dourado, F., Sineiro, F., Gama, F., \& Dominguez, H. (2004). Phisicochemical, functional and structural characterization of fibre from defatted Rosa rubiginosa and Gevuina avellana seeds. Journal of the Science of Food and Agriculture, 84(14), 1951-1959. http:// dx.doi.org/10.1002/jsfa.1902.

Montgomery, D. (2003). Diseño y análisis de experimentos (p. 21-125). México: Editorial Limusa S.A..

Official Methods of Analysis - AOAC. (1997). Association of Official Analytical Chemists (17th ed., William Horwitz, editor). Washington, DC: AOAC.

Oyaizu, M. (1996). Studies on products of browning reactions: antioxidative activities of products of browning reaction prepared from glucosamine. Japanese Journal of Nutrition, 44(6), 307-315. http://dx.doi.org/10.5264/eiyogakuzashi.44.307.

Prosky, L., Asp, N. G., Schweizer, T. F., DeVries, J. W., \& Furda, I. (1988). Determination of insoluble, soluble and total dietary fiber in food and food products: Interlaboratory study. Journal - Association of Official Analytical Chemists, 71(5), 1017-1023. http://dx.doi. org/10.1093/jaoac/71.5.1017. PMid:2853153.

Rhee, S., Lee, Y., Kim, M., \& Lee, C. (2004). Potential antioxidant peptides in rice wine. Journal of Microbiology and Biotechnology, 14, 715-721.

Rodríguez, R., Jiménez, A., Fernández, J., Guillén, R., \& Heredia, A. (2006). Dietary fibre from vegetable products as source of functional ingredients. Trends in Food Science \& Technology, 17(1), 3-15. http:// dx.doi.org/10.1016/j.tifs.2005.10.002.

Saiga, A., Tanabe, S., \& Nishimura, T. (2003). Antioxidant activity of peptides obtained from porcine myofibrillar proteins by protease treatment. Journal of Agricultural and Food Chemistry, 51(12), 3661-3667. http://dx.doi.org/10.1021/jf021156g. PMid:12769542. 
Sloan, E. (2001). Dietary fiber moves back into mainstream. Food Technology, 55(7), 18.

Van, P., Robertson, J., \& Lewis, B. (1991). Methods for dietary fiber, neutral detergent fiber, and nonstarch polysacharides in relation to animal nutrition. Journal of Dairy Science, 74, 358-397.
Zambrano, M., Melendez, R., \& Gallardo, Y. (2001). Propiedades Funcionales y Metodología para su Evaluación en Fibra Dietética. In F. Lajolo, F. SauraCalixto, E. Witting, \& E. Wenzel (Eds.), Fibra Dietética en Iberoamérica: Tecnología y Salud. Obtención, caracterización, efecto fisiológico y aplicación en alimentos (pp. 195-209). Sao Paulo: Varela Editora e Livrara Ltda. 